\title{
Villegagnon ou a utopia tropical
}

\author{
Serge ELMALAN
}

Resumo: Na primeira metade do século XVI, o território brasileiro sob domínio português era parada obrigatória nas viagens de navegadores e corsários franceses. Presença, em alguns locais do litoral, muitas vezes maior do que dos homens a serviço da coroa lusitana. A França, porém, não tinha um projeto de colonização. Apenas vinha aqui em busca de bons negócios. Mas a política do mundo mudava, e o interesse francês por um império colonial próprio motivou a expedição comandada por Villegagnon, que ambicionava fundar uma colônia francesa no Rio de Janeiro e desafiar, assim, o poderio português. Há 450 anos, em 1555, desembarcava na Baía de Guanabara uma grande expedição francesa, liderada por um homem que, influenciado por Thomas More e grandes intelectuais de seu tempo, ambicionava criar no Rio de Janeiro a sua própria sociedade ideal. Apresenta um Villegagnon desconhecido, personagem muito interessante. Não um corsário sanguinário como o descreviam os livros de história brasileiros. Mas um homem inteligente, de mente aberta e princípios sólidos, que por algum tempo viveu o sonho de uma sociedade livre sob o sol dos trópicos.

Palavras-Chave: Villegagnon; Utopia; Colonização Francesa; Intelectuais.

\footnotetext{
* Jornalista, editor, escritor e Secretário Geral da Association Dialogue France-Brésil. Em 2000, publicou "Villegagnon ou a utopia tropical" com prefácio de Jean-Christophe Ruffin, uma obra que retrata a efêmera epopéia da França Antártica. E-mail: elmalan.serge@yahoo.fr
} 
Lançado com sucesso na França e no Brasil, o romance "Villegagnon ou a Utopia tropical" junta este personagem histórico a outras grandes figuras de seu tempo. Mostra-o discutindo com Calvino, comendo com Rabelais e resgatando Maria Stuart. Um livro que retrata Villegagnon como uma das mais brilhantes mentes de sua época, alguém que ousou sonhar com uma civilização mais justa, edificada nas areias brancas das praias cariocas.

"Surpreendente e sedutor (...) a receita de Serge é original o suficiente para excitar até mesmo os paladares habituados aos sabores tropicais." — O Estado de S. Paulo.

"Embarquem com apetite (...) numa experiência única, necessária e (...) deliciosa." - Jean Christophe Rufin, autor de

Vermelho Brasil e O abissínio.

\section{As Utopias e o Novo Mundo}

2005 ficará como o "Ano do Brasil na França e 2009 como o "Ano da França no Brasil", uns anos ricos em comemorações de uma sedução mútua, fecunda, que perdura há cinco séculos. Exposições, eventos culturais e comercias, cinema, livros, documentários de televisão, intercâmbios universitários, conferencias, missões econômicas, novas tecnologias e acontecimentos de todos os gêneros, desde os fulgores das artes até os inúmeros shows das estrelas da música, Brasil e França nunca deixaram de estar em cartaz ao longo dessas homenagens plurais.

Nestas notáveis oportunidades, Franceses e Brasileiros descobrem, ou muitas vezes redescobrem as múltiplas facetas de umas culturas que os fascina desde que os navegadores normandos começaram, no início do século XVI, a explorar o litoral do novo mundo. A recíproca é da mesma forma verdadeira, pois a influência francesa no Brasil foi durante muito tempo dominante, senão hegemônica. Desde as efêmeras 
"França Antarctica" e "França Equinocial» instaladas com a fundação de Rio de Janeiro em 1559 e de São Luis do Maranhão em 1612, até a adoção da divisa "Ordem e Progresso" moldada na filosofia positivista de Auguste Comte e inscrita na bandeira nacional, as ligações entre os dois países não pararam de proliferar ao longo do tempo.

Constam também na memória dos brasileiros nomes franceses alem de Auguste Comte, guru do positivismo, como Allan Kardec, o "pai» do espiritismo, venerado por numerosos adeptos no Brasil, Claude Lévi-Strauss, Fernand Braudel, Paul Arbousse-Bastide, intelectuais e fundadores da prestigiosa Universidade de São Paulo (USP).

Os "anos do Brasil e da França" são tão bem-sucedidos que, considerando os projetos já em andamento, parecem ter desencadeado uma dinâmica capaz de fazer prosperar esse caloroso reencontro.

Porém, não seria a hora de imaginar um olhar sobre essa estranha e inoxidável amizade que dedicam um ao outro, desde que se conhecem, os países de Descartes e do Machado de Assis ? As idéias apresentadas aqui querem apenas constituir reflexões para a avaliação do papel dos franceses na escrita da nação brasileira. O nosso propósito e de evitar uma visão linear sobre o olhar estrangeiro e de procurar as fontes de certos traços importantes do imaginário brasileiro.

\section{Era uma vez a França Antárctica}

As historiografias brasileiras e francesas divergem sobre as primeiras alianças interculturais entre nativos e europeus no Novo Mundo. Mesmo assim, para o historiador Capistrano de Abreu, "durante anos ficou indeciso se o Brasil ficaria pertencendo aos Pêros (portugueses) ou aos Mair (franceses)".

De fato, na primeira metade do século XVI, o território brasileiro sob domínio português era parada obrigatória nas viagens de navegadores e corsários franceses. Presença, em 
alguns locais do litoral, muitas vezes maior do que dos homens a serviço da coroa lusitana.

Já sabemos que o nome Brasil não deriva da palavra portuguesa "brasa" ou "braseiro", como outrora os professores ensinavam às crianças. Sua verdadeira origem é o termo celta brésil, que significa "vermelho". Os franceses da Normandia, que logo após o Descobrimento se tornaram os primeiros traficantes de pau-brasil para a Europa, batizaram com esse nome a preciosa madeira vermelha que aqui vinham buscar. A palavra brésil difundiu-se a tal ponto que, segundo o historiador João Ribeiro, "Brasil" na verdade é um galicismo: o primeiro galicismo da língua "brasileira".

As relações que os franceses estabeleceram com as civilizações indígenas da costa brasileira foram, em geral, bastante cordiais e amistosas. Ao contrário dos portugueses, que vinham para conquistar terras e nelas se estabelecer, os franceses da Normandia queriam apenas fazer bom comércio. $O$ trato era tão cordial que foram produzidos logo "dicionários" normando-tupi-guaranis, contendo principalmente fórmulas de cortesia.

O tráfico dessa madeira deu origem a imensas fortunas na Normandia. Até aquela época, a cor vermelha era privilégio dos reis franceses. Os pigmentos que permitiam tingir de vermelho os tecidos eram caríssimos, inacessíveis à população. Com a chegada do pau-brasil tudo mudou. Qualquer dona-de-casa podia produzir em seu fogão doméstico as tintas para tingir seus tecidos com infinitas graduações de cores rubras. O pau-brasil permitiu que alguns armadores normandos, como foi o caso de Jean Ango, por exemplo, acumulassem poder e fortuna superiores às do próprio rei.

Ao mesmo tempo, o contato com as culturas indígenas produziu insuspeitadas e fortes influências na mentalidade francesa e depois na da Europa como um todo. Influências não apenas restritas à moda, como foi o caso do uso de penas e plumas nos chapéus - obviamente inspirado pelos cocares e adornos indígenas -, que se tornou moda avassaladora tanto para as mulheres quanto para os homens. 
Essas influências tiveram reflexos importantes na própria mentalidade e maneira de ser dos europeus. Naqueles tempos, o único modelo de organização social e de poder conhecido era o absolutista. O rei tinha direito quase de vida e morte sobre seus súditos, e pouquíssimos eram os que ousavam sequer imaginar uma situação diferente. Pois bem: muitos milhares de franceses vieram ao Brasil por causa do tráfico, marinheiros, oficiais, militares, comerciantes, gente da nobreza.

No contato com os índios, eles se deparavam com uma organização social e com uma postura de vida completamente diferente, infinitamente mais livre e feliz. Os índios andavam nus, o governo não era exercido de forma absolutista por um único indivíduo, mas sim repartido entre o cacique, o pajé e um conselho de velhos sábios da tribo; e a relação entre homens e mulheres era muito mais igualitária do que na Europa. Ao voltar para casa, nas ruas e praças, nas tavernas, nas casernas, na própria corte, os Franceses contavam o que tinham visto. Para resumir: tudo isso exerceu enorme influência, inclusive na formação dos vários movimentos humanistas que começaram a pipocar na Europa desde então.

Reflexos materiais dessas influências existem até hoje em vários monumentos arquitetônicos normandos, casas, palácios, igrejas, decorados com relevos em pedra ou madeira. Indios brasileiros que podem ser vistos ainda, esculpidos nas mais diversas situações, nas cidades de Rouen, Honfleur, Saint Valery e Dieppe, entre outras, dão uma idéia da dimensão que o contato entre normandos e índios brasileiros assumiu naquela época. Várias famílias indígenas foram inclusive levadas nos navios para a Normandia. A maioria nunca mais voltou. Alguns índios e índias acabaram se casando com brancos normandos, produzindo descendentes que até hoje moram lá. Em Rouen e Dieppe, no verão, costumava-se organizar festas "brasileiras", uma espécie de carnaval alegre em que boa parte da população se vestia de "índio" e saía pelas ruas a dançar. O pau-brasil foi motor de tudo isso.

No esquecimento da História, infelizmente rejeitado, o episódio inicial desse flerte franco-brasileiro, que virou 
permanente, oferece obviamente um cenário incomparável para descobrir suas raízes: a epopéia da França Antártica. Acontecimento que, desde 1555 até 1560, teceu, no lugar onde nascera a cidade de Rio de Janeiro, os primeiros laços entre os dois povos. Um personagem extraordinário foi o grande arquiteto desse idílio improvável entre os colonizadores franceses e os índios que moravam na região: o almirante Nicolas Durand de Villegagnon, um chefe militar implacável, mas também um humanista amante das belas letras.

A França, porém, não tinha um projeto de colonização. Apenas vinha aqui em busca de bons negócios. Mas a política do mundo mudava, e o interesse francês por um império colonial próprio motivou a expedição comandada por Villegagnon, que ambicionava fundar uma colônia francesa no Rio de Janeiro e desafiar, assim, o poderio português.

Há 450 anos, desembarcava na Baía de Guanabara uma grande expedição francesa, liderada por um homem que, influenciado por Thomas More e grandes intelectuais de seu tempo, ambicionava criar no Rio de Janeiro a sua própria sociedade ideal. O meu recente livro "Villegagnon ou a utopia tropical" tente retratar a história dessa aventura fadada ao fracasso. E apresenta um Villegagnon desconhecido, um personagem muito interessante. Não um corsário sanguinário como o descreviam os livros de história brasileiros. Mas um homem inteligente, de mente aberta e princípios sólidos, que por algum tempo viveu o sonho de uma sociedade livre sob o sol dos trópicos.

O Nicolas de Villegagnon, que todos conhecemos nos livros de história, é uma figura derrotada descrita pelos que o venceram. Um invasor francês, quase um pirata, que tentou usurpar dos portugueses uma terra que lhes pertencia de direito. Em "Villegagnon ou a utopia tropical", mais do que contar mas uma versão da primeira invasão francesa do Brasil, prefiro apresenta um Villegagnon maior. Um homem dividido entre idéias medievais e renascentistas, que parte para os trópicos com a missão de realizar o sonho de uma sociedade melhor. 
Sabemos que o descobrimento do Novo Mundo causou um impacto decisivo na "atmosfera mental" do período histórico definido como a Época Moderna. Essa influência favoreceu a redefinição de conceitos que foram fundamentais para impor o tipo de relacionamento que caracterizou o chamado processo de colonização efetuado sob a égide das metrópoles européias. Fundamental para a feição assumida por estes processos foi a construção da noção de "espaço vazio".

A colonização do século XVI e a descoberta das sociedades indígenas da América nos tempos da "França Antártica" puseram diante dos europeus uma nova forma de relação entre o território e seus habitantes. A quase ausência da noção de propriedade, em geral, mas particularmente 0 seu desconhecimento em relação à propriedade da terra - o Estado de natureza - impressionou profundamente o imaginário dos europeus. A impressão foi tão forte que a afirmação de uma nova definição dos "direitos de propriedade" estava se sobrepondo às noções tradicionais de espaço e apropriação.

Em substância, tal redefinição consistia em fornecer uma base jurídica moderna (Direito Romano) para a expulsão dos camponeses das terras que seus ancestrais ocupavam havia séculos e cuja posse e usufruto estavam garantidos pela tradição. O Estado de natureza encontrado na América deu nova vida aos mitos antigos sobre a existência de uma idade de ouro da humanidade, época sem conflito, quando a distinção entre o meu e o teu era desconhecido. É essa fonte que iria irrigar, dois séculos mais tarde, o pensamento utopista de Jean-Jacques Rousseau.

Foi assim que a lenda do bom selvagem e a admiração que os costumes indígenas causaram nos europeus influenciaram as idéias dos filósofos sobre a propriedade. Mas o mito serviu também de contraponto para os teóricos do Estado garantidor da propriedade, no seu conceito moderno, isto é exclusivo e excludente, acabando por se voltar contra os próprios selvagens, transformando-os em obstáculos a serem removidos.

O culto da natureza e os novos métodos de observação foram estimulados em parte pelo crescimento subitamente 
desmedido do mundo conhecido. As descobertas geográficas de Portugal e Espanha, de Bartolomeu Dias, Vasco da Gama, Cristóvão Colombo, e Fernão de Magalhães, entre outros, substituíram as visões feitas de ignorância e ilusão e revelaram aos olhos europeus a maior parte do universo. As novas terras abrigavam diferentes tipos de sociedades humanas com características totalmente inéditas e seus inusitados membros foram classificadas de selvagens.

Vale a pena lembrar que desde a queda do Império Romano até a Renascença, a Igreja católica estendeu sua influência por todo o conjunto de relações sociais e políticas que caracterizaram a Europa medieval. A sociedade desse longo período tinha sua economia organizada pelo feudalismo, onde o senhor feudal exercia sua suserania. Essa economia era essencialmente agrícola. Era permitido aos servos cultivar a terra pagando em troca ao senhor uma percentagem de sua produção.

A propriedade privada não era plena, pois os senhores nobres não tinham o direito de alienar sua propriedade. Não havia um Estado organizado, e os interesses políticos se confundiam com os interesses particulares. A Igreja passou a acumular o poder temporal e espiritual, e chegou a ter posse de cerca de um terço das terras da Europa. O clero é a principal ordem, e sua principal função é rezar. A segunda ordem é formada pela nobreza, e finalmente vêm os que trabalham, a terceira ordem. Nesse ponto, temos a contraposição entre o ócio e sua negação, o negócio. Essa diferença ia ocupar um papel de destaque no final da Idade Média. De fato, na sociedade medieval e até a Renascença, um indivíduo não podia ser compreendido fora da sua condição na esfera social.

Sabemos que a Renascença é um período que compreende o fim da Idade Média e o Início da Idade Moderna, entre os séculos XIV e XVI, e tem alcance em diversos campos da sociedade, do saber e da arte. Por causa disso, muitos estudiosos o classificam como um período de transição, não mais medieval, mas ainda não moderno. Autores recentes como 
Michel Foucault, no entanto, ampliaram o valor do Renascimento sustentando que ele constitui um sistema completo.

Esse breve resumo é necessário para entender a época de Villegagnon e da França Antártica marcada pelo aparecimento da tradição humanista, liderada por Thomas More, Rabelais e Montaigne entre outros. De fato, nessa época, os humanistas passaram a questionar o teocentrismo (isto é, Deus como centro de tudo), teoria até então predominante. Acreditavam que o homem devia ser o centro das investigações filosóficas. Os humanistas achavam que no período que compreende a Idade Média, acontecera um retrocesso, porque a humanidade se separara do modelo antigo. Propõe então, com a volta ao modelo clássico (grego e latino), uma antropocentrização da arte e das ciências. Com as inovações tecnológicas que surgiram na época, (tais como a bússola e a pólvora) a antiga visão do mundo já não atendia mais às exigências espirituais e culturais da sociedade, e a religião em decadência precisava ser repensada. $O$ mundo acordava de seu sono.

Thomas More foi um desses filósofos humanistas, amigo do maior deles, Erasmo. Homem de grande influência e cultura em sua época era, como Erasmo, um cristão. Porém, adepto do verdadeiro cristianismo, aquele que existiu em tempos remotos e foi se deteriorando até se tornar não mais espiritual e humilde, mas mercenário, político e suntuoso. No início do século XVI, época em que viveu More assim como Calvino e Villegagnon, a Igreja tinha alcançado níveis absurdos de deturpação da mensagem cristã original. O sistema de "loteamento" do céu fora institucionalizado, e a autoridade dos eclesiásticos era de tal forma exagerada que esses abusos acabaram por gerar as reformas protestantes.

Para comentar a utopia no século XVI é necessário considerar as idéias de Thomas More. Este pensador de origem inglesa foi um dos melhores representantes das ideologias humanistas que surgiram naquele período. No livro "A Utopia", percebemos o quanto a ironia de More ataca o luxo arrogante da Igreja e da nobreza. Nessa obra, Thomas More mostra o quanto a massa de camponeses tem que trabalhar a mais para sustentar 
aqueles que nada fazem, como é o caso de grande parte dos clérigos e dos nobres. Na utopia de More, todos cumprem a sua parte para que a ilha tenha superabundância de produção. Ainda no tocante à religião, os sacerdotes utopianos tem verdadeira autoridade espiritual e o prazer é tido como um grande bem, que traz a felicidade. O ascetismo na ilha é uma opção, mas pergunta More: Se o objetivo do asceta é melhorar a vida do mais próximo, porque não começar pela nossa própria casa e melhorar nossa própria vida? Assim como na ilha de Villegagnon.

Na utopia de More é notável a influência de "A república" de Platão, outra obra utopista que trata da sociedade ideal, a começar pela crítica à propriedade privada. Tantos os utopianos quantos os habitantes da cidade de Platão viviam em regime de comum-unidade.

A propriedade privada, comum na Grécia e recémressurgida à época de More, é vista como um empecilho à prática da virtude humana, ou do verdadeiro motivo para o qual o homem foi criado. Para More, o homem deveria viver de acordo com a natureza, daí seu esforço de defender uma nova civilização. O principal problema da civilização ocidental, para ele era o "monstro pestilento" do orgulho e do lucro, que seria o único motivo de os homens não terem uma sociedade igual à de Utopia. A nossa atualidade confirme essas duvidas proféticas!

A crença em um além-mundo é compartilhada tanto por More quanto por Platão, e essa crença serve de sustentação para se levar uma vida espiritualizada na Terra e garantir a validade de um esquema social planejado e muitas vezes imposto. A doutrina utopiana tem diversos pontos parecidos com a religião cristã. Villegagnon cita expressamente sua admiração por More e também por Platão e por alguns conceitos estóicos, mas achava impossível que a mente deturpada dos governantes ocidentais pudesse alcançar a maravilha de um tipo de sociedade igualitária, sem dinheiro nem vaidade. Visão moderna até hoje.

A hierarquia existe em Utopia, mas é diferente da que conhecemos. Há um grande fluxo de troca de cargos, e todos 
estão interessados só no bem-estar público. No demais, todos são iguais, numa escala que chega a ameaçar a pluralidade. De fato, a ilha inteira é como uma grande família. En Utopia, More defende esses dois modos de vida, comunitário e sem propriedade privada.

Assim como pensa faz muito tempo Claude Lévi-Strauss, todos os elementos fundamentais (história, dramaturgia e simbolismo dos acontecimentos, personagens descomunais, cenário majestoso...) nos parecem reunidos para fornecer a trama de um filme baseado numa reconstrução histórica focada nos cinco anos de existência da França Antártica. Transcritas em itálico, as cenas e os trechos do relato que segue nesses próximos parágrafos servem de suporte à exposição dos grandes eixos do roteiro desse filme imaginário constam do meu livro Villegagnon ou a utopia tropical publicado pela Editora Record.

Necessário à compreensão da dimensão do personagem central, o perfil que segue será construído através de diálogos e de situações explícitas :

\section{Um monge soldado invadido por uma utopia tropical}

Quem é esse singular almirante da marinha francesa que penetra em novembro de 1555 no comando de duas naus transportando 600 homens na exuberante baía de Guanabara descoberta em 1502 por uma esquadra portuguesa e confundida com a boca de um rio?

Esse nobre de espada com ares de monge soldado corpulento fez
voto de castidade em 1530, quando tinha vinte anos de idade, ao
aliciar-se na ordem dos Cavalheiros de Malta. Sob a bandeira do
Cristo, lutou contra os turcos na Hungria e em Argel. Ao cabo de
uma operação atrevida, resgatou a princesa católica Maria Stuart,
prometida ao rei da França e mantida em cativeiro num castelo
escocês. Longe de ser um mero e brutal espadachim, nosso
cavalheiro é também um exímio estrategista que gosta da poesia
de Ronsard e do humor satírico de Rabelais. Nicolas de 
Villegagnon é uma figura de seu tempo, um aventureiro esclarecido da Renascença que sucede à Idade Média obscurantista.

Ao embarcar para o Novo Mundo, ele nutre o sonho utopista de uma sociedade ideal imaginada por Thomas More, chanceler do rei da Inglaterra Henrique VIII e amigo do filósofo Erasmo. Financiada às escondidas pelo rei Henrique II que, como seu pai Francisco I, nunca aceitou o tratado de Tordesilhas sobre a divisão da América do Sul entre os domínios espanhol e português, a expedição liderada por Villegagnon tinha como missão o assentamento de uma colônia francesa num território português quase inexplorado.

\section{O descobrimento do «bom selvagem»}

A cena desenrola-se a bordo da Grande Ramberge. Villegagnon reuniu os seus homens mais próximos que formavam uma espécie de estado-maior.

E sem esperar, com uma voz lenta, mas poderosa e autoritária, Villegagnon, plantado diante da escrivaninha, dirigiu-se aos quatro homens cujas sombras, feitas pela luz das velas que morriam, dançavam nas paredes de madeira da cabine:

Não somos, pois, os primeiros a vir ao Brasil, mas temos boas razões para empreender essa viagem, como o fez antes de todos Jean Cousin, esse grande marinheiro de Dieppe que descreveu esse continente doze anos antes de Cabral e antecipando-se em quatro às façanhas de Cristóvão Colombo. Nosso rei Henrique considera com razão que todos esses exemplos são argumentos importantes para a contestação francesa do monopólio português sobre o Brasil. (...) Esta ocasião é para o rei o início de uma política francesa de conquista nas Américas, e isso por três razões: a descoberta, o comércio e a expansão.

$\mathrm{Na}$ véspera de alcançar o litoral brasileiro, os diálogos e as conversas a bordo da nau desvendam os objetivos da viagem e 
desenham os perfis do personagem central e dos principais personagens franceses da história:

- Nicolas de Villegagnon, chefe respeitado e temido, cujo comportamento beira muitas vezes o de um tirano.

- Bois-le-Comte, sobrinho e braço direito do almirante, muito mais diplomata que o tio, em suma, a encarnação de um certo "poder moderador" no seio do grupo. Vai se apaixonar por Iara, filha de um cacique, que lhe dará duas gêmeas.

- André Thévet, monge redondo e barrigudo, sempre vestido com uma velha vestimenta de sacerdote, que será um dos escrivães da expedição.

- Nicolas Barré, secretário particular do almirante, com um perfil de juiz grandalhão, discreto e mesmo apagado.

- Andrew Reed, chefe da guarda pessoal de Villegagnon, tem um imponente bigode cor de cenoura que combina com sua abundante cabeleira quase tão vermelha quanto seu uniforme da guarda escocesa.

Fazem também parte dessa lista os personagens secundários Le Thoret et De Sausacque, cavalheiros da Ordem de Malta como Villegagnon e o piloto Le Testu, que já tinha viajado até a baía de Guanabara dois anos antes.

Do alto de A Rosa dos ventos, grande e poderosa nau vinda da Bretanha, os marujos se alvoroçavam tocando-se com o cotovelo, debruçados na balaustrada, gritando de surpresa:

- Você viu, eles estão nus!

- O corpo delas é soberbo!

- $\quad$ E aqueles, com pinturas dos cabelos aos pés!

- $\quad$...é para não descascar no sol!

- $\quad$ Eles não têm barba!

Ao passar, Bois-le-Comte observou rindo que alguns manifestavam aos gritos suas inconscientes ambições antropófagas, embora fossem apenas, sem saber, os ingredientes de um possível banquete.

- Que bunda!

- $\quad$ Ah! aqueles peitinhos maravilhosos... da vontade de morder! 
Se os monstros e os dragões que eles imaginavam foram reduzidos a uma dimensão mais realista, descobriram, por outro lado, modos de vida extravagantes a seus olhos de "civilizados". Hábitos inauditos. Homens e mulheres vivendo completamente nus, como se ignorassem o pecado de Adão e Eva!

Invariavelmente pacíficos, os primeiros contatos com os nativos são todos marcados pela estupefação provocada entre os franceses pela sensualidade natural das índias. Trata-se de um verdadeiro choque de civilizações. O mundo da Baía de Guanabara revela-se, de fato, genuinamente novo para os católicos assombrados pelo pecado da carne. Para o casto Villegagnon e sua tropa de homens sem mulheres, a prova da tentação se anuncia particularmente muito difícil de suportar.

Logo ao desembarcar na ilha que leva hoje o nome de Villegagnon, os franceses se empenham em estabelecer as fundações do forte de Coligny e constroem, na praia do Flamengo, as primeiras casas de Henriville, assim batizadas em homenagem ao rei Henrique II. Paralelamente, fazem contato com os trugimoes franceses (les truchements) que participaram das expedições anteriores na região, que vivem com os índios, e que servirão, no começo pelo menos, de intérpretes. Os recémchegados lançam-se à descoberta dos indígenas agrupados em aldeias de ocas coletivas.

Ao desembarcarem na clareira que abrigava a aldeia de Cunhambebe e dos tupinambás, de início só perceberam o prolongamento animal de seu "araçoia", o estranho chapéu composto de imensas plumas que aureolava seu rosto nas grandes ocasiões.

Diante da porta de sua estranha casa, a estatura maciça de Cunhambebe acompanhava com grande atenção os preparativos de uma refeição. Um braseiro de barro projetava uma luzinha vermelha que ainda se arrastava junto da floresta. A chegada de Villegagnon e seus amigos não pareceu surpreender ninguém.

Exprimindo-se na língua do índio, tanto por um cuidado, mas hábil quanto por respeito às conveniências, e sem evitar efusivos 
abraços, o almirante, da mesma forma que o chefe Cunhambebe, dava a impressão de estar contente com o reencontro.

De espírito curioso, mal chegara Villegagnon se pôs a escutar a rica, lógica e eloquënte língua dos tupis. A sonoridade do dialeto, tão próximo dos ruídos da natureza, o cativava. Desde então vinha aprendendo com espantosa facilidade. A única pequena dificuldade encontrada para assimilar essa tradição oral residia na ausência de escrita, desconhecida e considerada pelos índios uma espécie de feitiçaria.

Os franceses aprendem os dialetos indígenas e respeitam os costumes desses índios antropófagos que o monge Thévet, autor das Singularidades da França Antártica, tenta com muita moderação de converter ao cristianismo, mais por obrigação do sacerdote que por convicção pessoal.

Sua obra devia contribuir para que fosse mais bem conhecido o país dos tupinambás, carijós, tamoios, tupiniquins e margageats, que aparecia nos mapas europeus sob os nomes de "Terra de Santa Cruz", "País dos papagaios» ou ainda "Terra dos Canibais». Na mente dos europeus, o canibal era o ser mais primitivo, aquele que, segundo Aristóteles, se achava na fronteiras do animal e do humano.

Assim a representação feita por Thévet de «nossos amigos os índios" ia impor a imagem do "bom selvagem», ainda que não apagasse a de devorador de carne humana do "bárbaro sanguinário». As impressões fortes da liturgia sangrenta praticada por grupos étnicos de Novo Mundo ainda permaneceriam por muito tempo ligadas ao Brasil. $O$ relato dessas aventuras, ricas de todos os ingredientes da literatura das obras de viagens, podia dispensar a ficção. Mesmo assim, na obra do pequeno monge, a força e o interesse não nasciam apenas da observação: às vezes resultavam do sonho e do imaginário exótico e não se nutriam só do autêntico.

O comércio de pau Brasil é intenso. Os embarques atingem rapidamente o ritmo de uma nave por dia em média. As informações afluem, provenientes de uma metrópole que logo será assolada pela Guerra das Religiões entre católicos e 
protestantes. Apressado em fortificar sua base na França Antártica, Villegagnon não se cansa de pedir em vão reforços ao rei. Porém, o ambiente é bom em Henriville. Frente à ameaça portuguesa, Villegagnon pode contar com aliados de peso: a confederação dos tamoios, um exército índio de vários milhares de guerreiros. A utopia tropical vive seu período dourado.

\section{Henriville castigada pela guerra de religiões}

Em 1556, acompanhado por alguns índios e um Thévet doente, Bois-le-Comte parte para França, obedecendo a uma ordem de Villegagnon, para buscar verbas e reforços. Os portugueses, que estão intensificando a colonização do litoral brasileiro sob o regime das capitanias hereditárias, acentuam a pressão sobre Henriville. Partidário da fundação da França Antártica, o almirante De Coligny é o homem forte e ambicioso da Corte do rei Henrique II. Acaba de trocar de lado enquanto a tensão - que explodira na noite sangrenta da São Bartolomeu de 1572 - já sobe perigosamente entre católicos e protestantes.

Mas o que inquietava Villegagnon estava contido no sentido das palavras utilizadas pelo sobrinho na sua carta . Parecia, segundo Bois-le-Comte, que o almirante De Coligny estava alinhado com os protestantes: os reforços anunciados (300 homens) contavam mais padres que largaram a batina e huguenotes com rudimentos de guerra civil que membros de um exército jesuíta de monges soldados em ordem de batalha, como o que estava em marcha com os portugueses no norte do país.

A idéia lhe parecia absurda: "Coligny protestante! Estão acontecendo coisas desde que me ausentei", supreendia-se dizendo em voz alta um Villegagnon perplexo.

Decidida em virtude de um estranho princípio, que ainda estava para ser demonstrado, segundo o qual os pastores da igreja reformada eram tão necessários à fé dos índios quanto teriam sido as cruzadas para a glória de Deus, a incrível iniciativa de Coligny era para Villegagnon um grave acidente da mente! 
Três novos personagens importantes entram em cena:

- Os pastores protestantes Pierre Richer e Guillaume Chartier, discípulos de Calvin recém-chegados de Genebra. O proselitismo inflamado deles vai imediatamente semear a discórdia entre os católicos.

- Igualmente calvinista e estudante em teologia, Jean de Léry será o sucessor do monge Thévet como escrivão da aventura. Seu livro Viagem feita na terra do Brasil é considerado por Claude Lévi-Strauss o primeiro relato antropológico.

Se a convivência com as índias desnudas já era difícil para os católicos, vai ser ainda mais complicada para os castos protestantes, sobretudo para o intransigente Richer:

- Entre os índios, é como se as mulheres não tivessem esperado a civilização para se exprimir! - deplorou Richer, louvando o rigor de Villegagnon quanto à punição para todos os que uviviam sem temor de Deus com messalinas índias». Léry juntou-se a ele e saudou com vigor essa medida, para ele um bom decreto. Acrescentou, no entanto, olhando de novo um indiozinho louro, que ele talvez não estivesse sendo seguido à risca. (...)

- Saibam que entre os nossos amigos índios, as iniciações à vida sexual e os ritos a ela ligados lembram aos homens a igualdade dos sexos e os deveres de cada um no seio da família. Sabem, aqui, a sociedade é bem mais elaborada do que imaginamos...", acrescentou um trugimao que os acompanhava.

- Ah! isso você pode dizer! Comparada à deles, nossa sociedade do Velho Mundo vai sexualmente muito mal. A exceção dos aristocratas, da lubricidade e dos lupanares deles, ainda estamos nos perguntando como trepar sem pecado", diz outro trugimao.

Considerando os índios uma causa perdida, os pastores protestantes nem tentam catequizá-los, mas o zelo deles redobra em Henriville, onde prometem o inferno aos fornicadores ímpios. Estão em todas as partes, mesmo na praia e a bordo dos navios, 
mesmo nas casas. Cada um defende com vigor a sua doutrina, todas elas diferentes e representando nada menos que sete seitas.

Villegagnon, que demonstra até agora uma tolerância religiosa exemplar, sente que a situação esta fugindo do seu controle. Tensas, as relações entre católicos e calvinistas desembocam num violento enfrentamento doutrinário a respeito da eucaristia. . Durante um culto celebrado no dia da Pentecostal de 1557, o pastor Richer provoca um escândalo.

Richer ficou furioso, começou a chamar de heréticos e sacrílegos, de falsários e impostores, todos os que misturavam água ao vinho da Ceia ou que sustentavam que se devesse fazê-lo. Léry, muito filósofo para entender o conceito de "substância" do corpo do Cristo e por aversão ao catolicismo, propôs trocar isso tudo pelos produtos regionais, mandioca ralada e cauim - a bebida preferida dos índios, uma cerveja fermentada nada menos que com a saliva da índias. Literalmente, uma senhora bagunça. $E$ outros vituperavam: com ou sem levedura? Vinho tinto ou branco? O antagonismo sobre o sagrado não acabava nunca. Cena inesquecível essa Ceia! (...)

O almirante, aliás, estava indignado. Se aos olhos dos calvinistas, partidários de uma interpretação simbólica do sacramento, os católicos que pretendiam ingerir "realmente" o corpo do Cristo eram totalmente assimiláveis aos canibais, outras pessoas de fato podiam se espantar com a incongruência desse conflito que assumia uma dimensão ainda mais forte uma vez que tinha como pano de fundo um canibalismo real.

$E$ difícil imaginar o que os índios acharam dessa briga ligada à eucaristia. Mas reagiram de acordo com a própria lógica quando receberam pela primeira vez o santo sacramento ao ingerir a hóstia que era o corpo mesmo do Deus Todo Poderoso: pensaram em devorar o monge missionário apos ter comido o Deus dele... Pois a eucaristia lhes lembrava um ritual muito concorrido: o churrasco de presos devidamente engordados no cativeiro!

- O corpo assim retalhado e cozido à moda deles, foi distribuído a todos, quantos fossem, cada um com seu pedaço. As mulheres 
receberam as entranhas e, e além dessas vísceras comeram as partes vergonhosas, as crianças que amamentavam, por sua vez, foram lavadas no sangue da vítima. Que Deus Tenha a sua alma. A cabeça? Não, não vamos exagerar, eles não comeram a cabeça, ela foi espetada na ponta de uma vara e colocada na entrada da aldeia. Que Deus os perdoe! Para encontrar um exemplo de crueldade tão excessiva, temos de voltar ao cerco de Jerusalém por Tito, quando a fome obrigou as mães a matar seus filhos par comê-los", contou Léry. (...)

Aproveitando a impotência do exílio, sentia-se livre de se encantar com a abundância natural desse Novo Mundo e de seguir um outro caminho nas suas relações com os tupis. Para ele, não se tratava de possuir o que pertencia aos outros, mas de aproveitar o ensinamento desses guias iniciadores, soberanos das florestas e da natureza, que olhavam os franceses não como invasores, mas como aliados.

Nutrida pelo respeito mútuo da diferença, a amizade franco-índigena revela-se inabalável. Enquanto brigam entre eles em nome do Cristo, os franceses de todas as confissões reforçam os laços com várias tribos, laços tecidos no início contra o inimigo comum português. $O$ ambiente cada dia mais pesado que reina no forte desencadeia uma migração crescente de seus defensores para Henriville que banha, de acordo com Villegagnon, em "uma promiscuidade bárbara de Franceses feitos selvagens».

Apesar dos pregadores calvinistas e do rigor de monge do almirante, os costumes decaem notavelmente na França Antártica. O próspero comércio de pau-brasil não está sendo ainda afetado pelos acontecimentos. Mas o descontentamento cresce entre os trugimoes dedicados ao comércio - proibido por Villegagnon - de crianças índias capturadas durante os ataques às aldeias de tribos inimigas.

Os traficantes de jovens escravos se vingam virando espiões dos portugueses, agora bem assentados na capitania vizinha de São Vicente, berço do Estado de São Paulo. Os pedidos de reforços feitos constantemente ao rei de França e ao 
almirante De Coligny ficaram todos sem resposta. A pressão aumenta sobre as posições francesas. O "pacto teológico», sinônimo para Villegagnon de uma tolerância religiosa necessária, não resistiu à convivência entre católicos e protestantes. A utopia tropical agoniza.

\section{A debandada da França Antártica}

Em novembro de 1558, uma nova investida anti-católica por parte dos calvinistas durante uma missa acaba de vez com a paciência de Villegagnon. Indesejáveis no forte Coligny, os mais fanáticos dos pregadores, entre eles os pastores Richer e Chartier, não se sentem em segurança na ilha. Alguns, como Jean de Léry, procuram um refúgio temporário nas aldeias dos índios, outros nas casas dos trugimoes de Henriville. Obedecendo a uma ordem de Villegagnon que não agüenta mais a presença deles nos arredores, todos embarcam rumo à França, algumas semanas mais tarde, a bordo de um velho barco que fazia água por todas partes, o Jacques.

Após quatro dias de navegação, enquanto a falta de víveres já se fazia sentir, cinco deles preferem voltar à baía de Guanabara a bordo de um barquinho (chaloupe). Logo que chegariam à Henriville ao cabo de uma jornada de pesadelo em alto mar, serão as vítimas de uma paródia de julgamento e condenados a forca por conspiração. Assim foi o fim trágico dos últimos calvinistas de uma França Antártica agora na mira dos portugueses, e cujo chefe impiedoso deixa-se invadir por um baixo astral a cada dia mais flagrante.

Só os índios se espantaram com o espetáculo: a estranheza e a nova maneira que os franceses tinham de fazer festa e honrar seu Deus. ... Enfim, junto com os índios, alguns franceses se espantaram também, $E$ mais que eles, Bois-le-Comte, leal à aliança estabelecida com os índios, militante entusiasta

Todos à volta do almirante insistiam com Bois-le-Comte para que convencesse Villegagnon de que uma única ação ainda poderia 
salvar a França Antártica: defender sua causa em Paris. Ele precisava bem rápido pedir uma audiência ao rei Henrique, fazer intervir, se fosse preciso, Diane de Poitiers, a amante do rei, os Guise, a influente familial que comandava o campo católico, ou o general Du Bellay. Obter ajuda tornava-se condição indispensável à salvação da obra empreendida.

Enquanto prepara sua viagem da última chance à Paris, Villegagnon, prestando ouvido aos rumores que circulam a respeito do Eldorado, manda seu sobrinho explorar a bordo da Petite Ramberge o litoral sul até o Rio da Prata em busca de ouro e de pedras preciosas, pois aquelas riquezas, se encontradas, não deixariam de aguçar o interesse de seus interlocutores na Corte quanto ao futuro da França Antártica. $\mathrm{Na}$ ausência de Villegagnon e de Bois-le-Comte, é o cavalheiro De Sausacque quem cuida da administração do forte. Uma profunda decepção espera Villegagnon na metrópole.

Logo que chegara à França, Villegagnon tomou conhecimento com uma evidente consternação que o rei Henrique tinha recentemente falecido, seguido de seu irmão Francisco II meses mais tarde, uma real hecatombe. Depois, enumerou os longos trâmites feitos para ser recebido pela regente Catarina de Médicis que, no estado caótico do reino, não lhe deu esperança alguma quanto aos reforços esperados.

Alistado na hora no exército católico na guerra contra os protestantes liderados por seu antigo aliado Gaspard de Coligny, Villegagnon nunca mais voltara ao Brasil. O personagem central deixa o palco no momento que a frota portuguesa agrupa-se apostando na potência de fogo de vinte e seis galeões vindo da Bahia, de São Vicente e até da África.A incapacidade demonstrada pelo governador-geral Duarte da Costa em expulsar os invasores franceses das terras brasileiras teve um preço a ser pago. Foi destituído do cargo e no seu lugar fora nomeado o Fidalgo Mem de Sá.

Somente no Final do ano de 1559, após receber uma valiosa informação de um fidalgo francês capturado, Mem de Sá parte de Salvador em direção a colônia francesa. 
Em 15 de março de 1560, sexta-feira, teve início o combate. $\mathrm{Na}$ noite de Sábado, alguns portugueses e mamelucos brasileiros conseguiram penetrar de surpresa no forte e tomar uma das baterias. Por ai, apesar da reação dos franceses, os demais soldados de Mem de Sá entraram e tomaram o local. Cerca de 200 franceses e 800 tupinambás conseguiram fugir para o continente. Somente em 1567 os franceses são completamente expulsos do litoral do atual estado do Rio de Janeiro e o fim da guerra da confederação dos tamoios (esta guerra fora insuflada pelos remanescentes franceses do forte de Coligny).

A confederação dos Tamoios é um exemplo da organização social deste grupo. A grande nação Tamoio, subdividia-se em um sem número de pequenas tribos, autônomas, cada uma com seus próprios chefes e costumes. Porém, havia um "Conselho Superior", chefiado pelo notável cacique Caoquira, formado para decidir questões de maior importância. Neste caso, o grande problema a resolver era a aceitação ou não da presença do invasor português em suas terras.

As queixas dos Tamoios contra as atrocidades praticadas pelos colonos eram infindáveis e, pela visão de alguns caciques, só seria resolvida com uma guerra. Os franceses, interessados no enfraquecimento da presença portuguesa no Brasil, davam apoio e incentivavam a luta. A Confederação dos Tamoios foi a primeira experiência de uma frente ampla contra a invasão portuguesa ao Brasil. Este movimento reuniu, além de índios tupinambás, que eram maioria, os membros das tribos goitacazes, aimorés e outras menores na área litorânea. A primeira tarefa do novo chefe foi encontrar-se com Villegagnon, que havia acabado de chegar para estabelecer a França Antártica.

Os corsários franceses foram de fato, e durante séculos, uma pedra no sapato da coroa portuguesa, ameaçando o litoral e principalmente a região do Rio de Janeiro. Inconformados com o Tratado de Tordesilhas, que dividia as regiões descobertas no novo mundo apenas entre Portugal e Espanha, os corsários franceses se fizeram presentes por toda a costa brasileira, 
invadindo, saqueando, sabotando e estabelecendo vínculos comerciais com os índios locais. No Rio de Janeiro os franceses conquistaram a simpatia dos temíveis tamoios, índios belicosos liderados pelos caciques Cunhambebe e Aimberê, donos das terras que iam da baía de Guanabara aos limites de Paraty, incluindo a Ilha Grande em Angra dos Reis. Naus francesas utilizaram largamente a baía da Guanabara para reabastecimento de suprimentos e acabaram estabelecendo um vínculo forte com os índios descontentes com a invasão portuguesa, incentivando-os a boicotar a presença dos colonizadores.

\section{A utopia traduz a esperança}

Assim como a maioria das utopias, a utopia da "Franca Antartica" estimula a reflexão crítica sobre uma determinada época: seu projeto imaginário, seu ideal, é sempre concebido em função dos valores dominantes na sociedade. A idéia básica da maioria das utopias é a de criticar o presente pensando em como mudar o futuro. Assim como a Utopia de More, a utopia da "França Antártica" pertence ao gênero das teorias sobre a sociedade ideal, como é o caso de A república de Platão e A Cidade do Sol, de Campanella.

A utopia se manifesta pela invenção de um outro mundo, re-elabora a imagem mítica dos reinos da abundância, do bem estar, físico e espiritual, da ordem e da organização, tenta elaborar um novo futuro, propondo modelos de sociedades alternativas, comunitárias muitas vezes, sem os vícios daquelas reais, ou mesmo propondo plataformas de ação política em cidades ideais, ou ilhas paradisíacas. Para alguns utopistas, trata-se de restablecer o homem na sua integridade e em perfeita harmonia com a natureza.

Desfavorável para as populações indígenas, esses primeiros contatos dos europeus, portugueses e espanhóis, tinham provocado entre os intelectuais europeus, principalmente entre os religiosos, uma reação de proteção dos "direitos" destas 
populações. No início, foram intelectuais europeus como Bartolomeu de Las Casas e Montaigne que se perfilaram ao lado dos índios para defender-lhes a humanidade da alma e se recusaram a rotulá-los como bárbaros.

Três anos antes da chegada de Villegagnon no Brasil, em 1552, o frade dominicano Bartolomeu Las Casas publicou a Brevissima relación de la destruyción de las Indias (escrita em 1542) e deu início, na Espanha e na Europa, a um debate sobre a responsabilidade dos conquistadores no desaparecimento de 24 milhões de índios na primeira metade do século XVI (somente no México, nos doze anos que se seguiram à entrada de Cortés, morreram 4 milhões). Estes dados fornecidos por Las Casas não podem ser tomados como fonte primária, mas as pesquisas recentes não desmentem severamente suas estimativas.

Las Casas atribuiu aos excessos da conquista militar os resultados trágicos deste balanço. $\mathrm{Na}$ esperança de redimir a colonização, dedicou sua vida e sua obra a lutar para pôr fim à escravização dos indígenas e obrigar os espanhóis a restituírem aos seus verdadeiros donos as terras e bens arrebatados. Embora essa utopia realista não tivesse a intenção de deslegitimar o império espanhol, ou solapar os direitos possessórios da Coroa espanhola, os escritos de Las Casas fizeram grande sucesso no exterior e difundiram na Europa a famosa leyenda negra: seu livro teve quinze edições holandesas, treze francesas, sete inglesas, seis alemães, três italianas, três latinas, uma portuguesa e uma japonesa. Em contraste, na Espanha, a segunda edição da Brevíssima só chegou em 1646.

Las Casas foi, portanto, um dos primeiros defensores dos direitos dos índios americanos às terras que ocupavam, e muito antes dos antropólogos, assinalou a mecânica do enfrentamento cultural, que resulta, inevitavelmente, na desarticulação e na fusão das culturas dominadas. Percebeu, durante a sua vivência americana, que as culturas índias - independentemente da sua bondade ou maldade - seriam inevitavelmente modificadas e destruídas pela ação de outras culturas, não perniciosas em si mesmas mas agressivas no seu contato com aquelas. Entretanto, o desejo de proteger os índios americanos não serviu 
de remédio aos seus sofrimentos, porque criou e difundiu a idéia de sua inferioridade, e de sua pouca aptidão para defender-se sozinho.

Na realidade, já foi observado que o interesse despertado pelos indígenas da "França Antártica" sobre o homem da Renascença foi maior do que o interesse suscitado pelos novos territórios, porque a situação do índio americano remetia-o aos mistérios da sua própria imagem primitiva. Descrições da situação idílica na qual viviam os habitantes do novo mundo permeavam o relato dos viajantes do século XVI.

De fato, no longo processo que constitui a Modernidade, a construção recíproca do Velho e do Novo Mundo teve como um de seus principais agentes o viajante, sob as mais variadas roupagens: conquistador, aventureiro, missionário, peregrino. Movido por um projeto utópico, traria em sua bagagem imagens duradouras, fragmentos de discursos e relatos que se entrelaçam na voz desse novo narrador, que ao mesmo tempo descreve, inventa, critica, provoca, articulando ou reinventando representações que se incorporarão cedo ou tarde ao imaginário coletivo.

Para os escritores-viajantes que acompanhavam Villegagnon, como os franceses André Thevet (Singularidades da França Antárctica, 1558) e Jean de Léry (Viagem à Terra do Brasil, 1578), o Brasil era como uma tela onde se projetava a imaginação do Velho Mundo, ainda contaminada pelos bestiários medievais. Um olhar sobre si mesmo e sobre o outro, invertido no espelho.

As obras desses viajantes a respeito da vida dos índios nas terras da América portuguesa frisavam a felicidade dos habitantes e a ausência da propriedade privada. É, sobretudo, da "terra dos papagaios" que vem a imagem da América fabulosa e exótica, com seus "bons selvagens" emplumados, seus monstros e ritos de canibalismo.

Muitos outros relatos de viajantes foram escritos ou traduzidos para o francês e ajudaram a propagar o mito da "idade de ouro da humanidade". Os relatos de Américo Vespúcio (1503), Hans Staden (1557), Pero de Magalhães 
Gandavo (1576) enfatizavam mais os aspetos ferozes dos costumes indígenas. Mas outros estavam mais fascinados pelo Estado de natureza no qual o homem podia realizar todos os seus desejos (inclusive de violência), e no geral, o mito do bom selvagem fixou-se mais no imaginário, do que a característica de "devorador de homens".

Um dos aspetos mais interessantes da lenda oriunda do contato dos europeus com os habitantes do novo mundo foi a relação estabelecida entre a bondade natural do homem e a existência de uma "idade de ouro da humanidade", invariavelmente caracterizada pela inexistência da propriedade privada (ou por sua presença mínima)...

Espalhava-se a idéia, de modo geral correta, de que os habitantes do Brasil não conheciam o patrimônio, nem a propriedade, sendo todos os seus bens possuídos em comum. $\mathrm{O}$ aspeto mítico consistia na crença de que, graças a essa característica da sociedade indígena, os selvagens viviam num permanente estado de felicidade e que esse "estado de natureza" correspondia a um estágio primitivo da história da humanidade.

O próprio Las Casas, apesar de conhecer os índios americanos desde muito jovem, costuma ser lembrado como tendo difundido uma espécie de versão religiosa e avant la lettre da lenda do bom selvagem.

$\mathrm{Da}$ literatura descritiva a lenda expandiu-se para a literatura de ficção e a especulação filosófica, penetrando a obra de alguns dos maiores nomes do século XVI. Na França, a lenda do bom selvagem encontra-se em Montaigne e Ronsard, e mais tarde Rousseau. Na Holanda, algo dela subsiste em Erasmo.

Na Espanha, com a famosa obra de Miguel de Cervantes, o mito aparece nas palavras proferidas por D. Quixote aos pastores, exaltando a idade de ouro, a época quando o meu e o teu - pomo da discórdia dos dias que corriam - não eram conhecidos.

Foi justamente observado, entretanto, que apesar de integrante da geração posterior a Pizarro e Cortez, Cervantes não localizou sua utopia na América, provavelmente porque seu 
objetivo fundamental era fazer a apologia do cavaleiro errante medieval, que deveria trazer de volta a idade de ouro. Já o mártir do catolicismo, Thomas More, inspirou-se na Antiguidade clássica para a construção da Utopia, sociedade onde predominava um coletivismo autoritário e não um comunismo paradisíaco, mas na qual seus habitantes tinham em comum com o selvagem da lenda a propriedade coletiva do solo, e a existência feliz que, presume-se, era resultado deste regime.

Provavelmente foi Montaigne (1533-1592) o mais importante difusor do mito ou da utopia do Bom selvagem. De fato, Montaigne foi o primeiro a introduzir na literatura francesa a idéia do homem naturalmente bom, considerando os índios superiores aos invasores europeus, atribuindo-lhes grandes doses de bondade, lealdade, franqueza, liberalidade, coragem, firmeza e boa fé. Montaigne teria, ao mesmo tempo, dado outro alcance ao mito, indo além da simples constatação de que os selvagens viviam em condições de moralidade e felicidade, erigindo em princípio a superioridade do estado natural, esta glorificação da natureza. Ao mesmo tempo em que os felicitava por ignorarem as instituições e as invenções civilizadas, não enfatizava $\circ$ papel que desempenharia a ausência da propriedade privada nesta "felicidade".

Não obstante tais desenvolvimentos, ainda por muito tempo continuaria prevalecendo na Europa, com relação ao Novo Mundo, certa visão fantasiosa que, para muito além do que os olhos podiam ver ou a razão admitir, alimentava-se de narrativas extravagantes de viagens imaginárias ou sobrenaturais, tais os que falavam das guerreiras Amazonas. De todos os hábitos dos naturais do Novo Mundo, nenhum causaria decerto maior espanto entre os europeus que a antropofagia, causa aliás de constantes discussões filosófico-religiosas acerca da verdadeira índole desses gentios, descendentes de Adão e Eva para alguns, mas para outros pouco mais do que bestas-feras, o que de resto propiciava um bom pretexto de escravizá-los. Seria necessário que, em 1537, uma bula papal reconhecesse explicitamente a natureza humana dos americanos. 
Como percebemos, as primeiras décadas do séc. XVI presenciaram, além de uma revolução sem precedentes no campo dos conhecimentos geográficos, da navegação marítima e da cartografia, o primeiro e mais durável contato de ampla escala entre os europeus e os habitantes de regiões remotas da América, África e Ásia; ao mesmo tempo em que isso se passava, profundas mudanças conceituais ocorriam na arte da pintura, que deixava de ser dócil instrumento a serviço do papa ou do rei para, sob o influxo do Humanismo, dedicar-se ao homem e à natureza, como exemplificam, de modo insuperável, as obras de Leonardo da Vinci, Hyeronimus Bosch ou Albrecht Dürer. Sem falar de Rafael e Michel Angelo, todos contemporâneos de Villegagnon.

As alegorias foram imagens comuns na representação do continente americano e do Brasil no início da conquista européia. Fazem parte da iconografia utopista que tomou como referência o paraíso perdido e reencontrado. Dürer e Burgkmair, assim como Theodor de Bry e outros grandes artistas dessa época, jamais viajaram no alem mar nem viram um nativo brasileiro.

Esses "americanos", porém, começaram desde muito cedo a chegar à Europa, levados por colonizadores e marinheiros. Assim é que habitantes da Terra Nova foram levados para Portugal em 1501 e para a Inglaterra em 1502; astecas visitaram (à força) a Espanha em 1529; sabe-se de um índio brasileiro na Inglaterra em 1532 e de outro - o célebre Essomeriq - na França no mesmo ano; hurões foram trazidos para este mesmo país em 1536 e uns 50 índios brasileiros participaram, em 1550, da entrada de Henrique II em Rouen; sem falar daqueles levados em 1613 à França para ali serem batizados. Não havendo indicação de ter Cabral levado índios a Portugal, ignora-se, portanto, se Colombo ou Cabral levaram a bordo nativos americanos, ao regressarem de suas viagens de 1492 e 1500.

Em conjunto, as representações que os europeus faziam dos índios deram ao continente o sabor de uma fantasia provocante e ambígua encarnando ora a terra do canibalismo e da barbárie, avessa ao construto da cultura; ora o lugar por 
excelência da harmonia do homem com a natureza e território palpável do Paraíso desvendado para confirmar as Escrituras. Para enriquecer esta mística utópica, contribuíam a beleza da natureza e o ameríndio, o homem do novo mundo.

Desde sempre, os corsários franceses foram de fato uma pedra no sapato da coroa portuguesa, ameaçando principalmente a região do Rio de Janeiro. Inconformados com o Tratado de Tordesilhas, que dividia as regiões descobertas no novo mundo apenas entre Portugal e Espanha, os corsários franceses se fizeram presentes por toda a costa brasileira. Essa realidade pode ser ilustrada por Dugay-Trouin, outra figura importante e muitas vezes esquecida na história do Rio de Janeiro.

Ele represente mesmo o melhor exemplo da historia entre os dois pais esse René Duguay-Trouin, um dos mais audazes personagens de seu tempo, que chegou ao Brasil numa esquadra de 18 navios, com quase seis mil homens e 700 canhões, para saquear o ouro que era embarcado no Rio de Janeiro e seguia para Portugal. Executou o plano com sucesso e tomou a cidade como refém durante cinqüenta dias, enquanto aguardava o pagamento do resgate para devolvê-la a seus habitantes, depois de encher os navios com o ouro carioca para partir, deixando-a dilapidada.

A bem-sucedida invasão de Duguay-Trouin funcionou como vingança pessoal para ele - um ano antes, um outro corsário francês, Jean-François Duclerc, tentou invadir o Rio, com cinco navios e mil homens, mas fracassou, terminando preso e assassinado misteriosamente -, além de representar um grande lucro para a França. As motivações de Duguay-Trouin eram bem mais amplas que as do corsário que o antecedeu. Pretendia deslocar o eixo da Guerra de Sucessão Espanhola da Europa, já que a França, que se batia nos mares contra uma poderosa coalizão formada por oito países, vinha sofrendo muito naquela guerra. Com a marinha agonizante, atacar o Rio seria uma maneira de eliminar os inimigos da França aos poucos, pelas beiradas, longe do seu poderio militar. Ou seja, atacar o Rio, na época a mais florescente colônia portuguesa, era atacar 
Portugal, eterno aliado dos ingleses e parte da coalizão européia que estava em guerra contra a França.

Com um fim nada heróico, a história de Duguay-Trouin, herói na França e vilão no Brasil (como Villegagnon?), remonta a um tempo de aventuras e desventuras, de marinheiros, piratas e emoção de deixar o leitor tonto.

Em meio a tantas guerras, vendavais, tempestades, naufrágios, heroísmo, sonhos e sacrifícios humanos, as outras tentativas francesas no Brasil são, ao exemplo da "França Antarctica", utópicas e originais.

De fato, apesar do fracasso do projeto colonial da França Antártica, os franceses não

abandonaram o comércio nem os projetos no litoral brasileiro. No final do século XVI eles se encontravam na região norte do Brasil. Em 1610 , Henrique IV apoiou uma outra colônia de povoamento no Brasil sob o comando de Daniel La Touche de la Ravardière. Mas o malogro da França Equinocial (1612-1615), repetindo a experiência francesa no Rio de Janeiro, fez com que a Coroa francesa concentrasse seu empreendimento no norte.

Assim, e desde a descoberta do extremo norte brasileiro, Franceses e brasileiros brigaram pelo domínio das terras acima do rio Amazonas. As terras do Amapá se transformariam logo, mais adiante, no século XVIII, em motivo de conflito entre brasileiros e franceses. Estes reivindicando pra si a posse da área. A solução inicial para o impasse franco-brasileiro, saiu no dia 11 de abril de 1713, quando foi assinado o Tratado de Utrech, estabelecendo o rio Oiapoque como limite entre o Brasil e a Guiana Francesa. A solução não foi respeitada pelos franceses, que a transformaram em letra morta, perseverando durante anos na travessia do Oiapoque.

A cobiça pelas riquezas destas paragens criou o cenário para uma luta de três séculos que só terminaria no século $X X$, com a vitória diplomática que assegurou ao Brasil as terras que hoje compreendem o Estado do Amapá. Até chegar a esse ponto, não foi fácil. Até o final do litígio, muitas dúvidas sobre a posse das terras do Amapá ainda colocariam franceses e brasileiros em pé de guerra. A história do conflito franco- 
brasileiro se inicia pra valer em 1841, com a neutralização da área situada entre os rios Oiapoque e Amapá Pequeno, sobre a qual os litigantes, franceses e brasileiros, não teriam direito, até que todas as dúvidas a respeito fossem dissipadas $\mathrm{A}$ isso se sucederam algumas investidas no sentido de uma solução diplomática para o impasse, todas sem o resultado esperado.

As disputas precipitaram a construção da Fortaleza de São José de Macapá, e trouxeram à cena os corsários franceses, estimulados por Claude d'Orvilhares, governador da Guiana, quando as incursões estrangeiras foram mais intensas na região. Em 1885 houve os arroubos do romancista e membro da Sociedade de Geografia Francesa, Jules Gross, carregando um sonho transformado em realidade, mas logo desfeito, a caricata e efêmera "República do Cunani", criada por ele na região do Contestado. Mas o fim da republiqueta foi logo decretado. Uma Segunda tentativa é colocada em prática em 1902, quando Adolph Brezet tentou continuar os planos de Gross. Desta vez, foi o governo brasileiro quem freiou seus ânimos. O conflito chamou atenção do mundo e dois anos depois, Brasil e França assinam termo de compromisso, no Rio de Janeiro, confiando a resolução do conflito a uma arbitragem neutra, a do Presidente da Confederação Suíça.

Alias, a descrição fantástica de novos mundos e sociedades e os relatos de viagem constituem um tema comum às utopias e à ficção científica. Estas "viagens no tempo", tão características das histórias de ficção científica, se interpenetrariam com os relatos de viagem e descrição de novas sociedades, típico das utopias clássicas, constituindo, de uma certa maneira, as primeiras histórias de ficção científica, ainda quando esta não existia como tal. Constatamos também que as primeiras histórias de ficção científica começam com a descrição de mundos utópicos, ainda na Renascença. Não é gratuito que alguns autores classifiquem essas histórias numa categoria, apenas didática, da proto-história da ficção científica.

Constatamos então que desde a época de Thomas More e de Villegagnon até agora, a humanidade tem vivido ou assistido 
guerras e conflitos diversos a favor ou contra as variadas formas de política, religião e economia que foram surgindo ao longo dos séculos. Tudo em nome de anseios e desejos de bem estar comum ou individual, conforme a utopia de cada um, de cada nação ou de cada governante em nome de sua nação.

Esses laços e brigas que ligam desde sempre franceses e brasileiros ao longo de cinco séculos anunciam a "história de uma paixão, ora frenética, ora letárgica". Mais ao contrário do que se imagine geralmente, a França não acha que o Brasil seja só a pátria do futebol, do carnaval e da bossa nova. Se o jet set francês, idiota como todos os jet set do mundo inteiro, só conhece do Brasil as praias do Rio e a cirurgia plástica, a inteligência francesa não ignora que, cinco séculos depois de Jean Léry, Villegagnon e Montaigne, prossegue no Brasil uma fabulosa aventura social e cultural e expressa bem o paradoxo virtuoso e complexo da relação entre franceses e brasileiros. Esses "respingos das fagulhas do acaso", para usar a expressão de Gilles Lapouge, são visíveis ainda hoje, seja de forma mais luminosa ou envolta em uma segunda pele mais difusa, nem propriamente brasileira nem unicamente francesa. Essas faíscas, com mais ou menos combustão estão também presentes na história do patrimônio

arquitetônico brasileiro, tanto quanto aquecem gostos, estilos intelectuais, modos de falar.

Essa visão telescópica da influência do pensamento francês no Brasil denota afinidades intelectuais e cumplicidades teóricas.. Ela também peca certamente pela falta de nitidez e precisão Não há mesmo outra maneira de expor essas vivências cognitivas.

Mesmo que toda a generalização seja perigosa, poderíamos estimar modestamente, com o mesmo critério de grandeza, a influência dos gregos no pensamento ocidental e a dos franceses no pensamento brasileiro. Um berçário de idéias. $\mathrm{E}$, ainda que saibamos que o pensamento não tem pátria nem nacionalidade, sabemos também que ele precisa de um lugar para nascer e incubar, tanto quanto de territórios que favoreçam a sua maturação e metamorfose. 
Em parte, o Brasil tem sido um nincho fecundo para a metamorfose de um pensamento hoje não mais propriamente francês, nem genuinamente brasileiro. A Igreja Positivista Brasileira inspirada por Allan Kardec, convive com o ideário expresso em "Os miseráveis de Victor Hugo". Essa mestiçagem paradoxal estaria "na base da tradição moral e intelectual da elite brasileira", acrescida das idéias de Anatole France, a quem os acadêmicos brasileiros recebem em 1909. Graças a esses utopistas "históricos" podemos dizer hoje, sem nenhuma dúvida, que inúmeras das exigências ou reivindicações utópicas levaram a avanços sociais, inegavelmente.

Villegagnon não foi apenas interessante para o começo da fundação do Rio. Ele foi muito mais. Estadista, militar e intelectual de boa cepa, trocava cartas com Rabelais, Ronsard e Calvino, além de amigo de três reis de França. Portanto, a altura política e os atos heróicos de Villegagnon surpreendem e encantam. Como, por exemplo, o seqüestro da ainda menina Maria Stuart, retirada das brumas da Escócia através de uma espetacular ação militar por ele planejada. E realizada com tal sucesso que deixou a já poderosa armada da Grã-Bretanha a ver, literalmente, navios.

O episódio - que o consagrou em toda a Europa renascentista como um "grand chevalier" e um estrategista, ocorreu bem antes de sua frustrada empreitada às margens da baía de Guanábará. Portanto, e antes de qualquer outra consideração, a figura de Villegagnon nos será, a partir da recuperação histórica que deve ser agora empreendida, objeto de justo orgulho e de absorção oficial. Cariocas e outros brasileiros, com certeza, passarem a lhe dever interesse e melhor reconhecimento.

Mas, por que, afinal, Villegagnon passou quatrocentos e cinqüenta anos no limbo da história do Rio e do Brasil? Por duas razões, que se entrelaçam na trama sibilina do banir de memória na rolagem dos séculos. A primeira, é claro, porque a história oficial é sempre feita e escrita pelos vencedores. E os portugueses, que acabaram por destruir Henriville em 1560, quando Villegagnon estava em Paris (à procura de reforços para 
sua colônia carioca), jamais iriam proclamar que o Rio foi prefundado pelos franceses. A segunda razão é porque Villegagnon mereceu citação desabonadora dos reformados depois das querelas religiosas entre calvinistas e católicos, que acabaram por enlamear e destruir o primeiro núcleo civilizatório europeu no Brasil.

Sempre foi difícil, para os historiadores, acreditar-se que seu sonho de instalar nos trópicos uma pátria francesa ficou frustrado pelos embates religiosos que acabariam por mergulhar a França, sempre propulsora de novas idéias e ideais, na guerra civil. E que culminariam com a tragédia que foi a noite de São Bartolomeu, menos de vinte anos depois da expedição francesa à Guanabara. Mas foi precisamente isso o que ocorreu.

Portanto, não podemos esquecer que com Villegagnon e a "França Antarctica", o Rio de Janeiro nasceu pluralista, universalista e inundado pelos confrontos intelectuais. O Rio nasceu com uma figura lendária da Renascença francesa, reconhecido herói em todas as cortes da Europa. A exceção, por certo, da corte portuguesa, que nele não via nenhuma graça. Nem encanto. Encanto e importância que agora deveriam ser celebrados por nossos dois país em 2009 "ano da França no Brasil".

ELMALAN, Serge. Villegagnon or the tropical utopia. História, v.27, n.1, p. 247-282, 2008.

Abstract: In the first half of the XVI century, the Brazilian territory under Portuguese domination was a mandatory stop during the voyages of French navigators and corsairs. Their presence was at some places along the coast many times more frequent than that of those at the service of the Portuguese crown. France however did not have a colonization project. They just came in search of good business prospects. However, the world's politics changed, and the French interest in having its own imperial colony, inspired an expedition commanded by 
Villegagnon, who had the ambition of founding a French colony in Rio de Janeiro and challenged in this way the Portuguese power. Four hundred and fifty years ago in 1555, a large French expedition landed in Guanabara Bay led by a man who had been influenced by Thomas More and great intellects of his time, and had the ambition of creating in Rio de Janeiro his own ideal society. An unknown Villegagnon came onto the scene, a fascinating person. Not a bloody corsair as he is described in Brazilian history books, yet an intelligent man, with an open mind, and solid principals, that for some time had lived the dream of a free society under the hot tropical sun.

Keywords: Villegagnon; Utopia; French Colonization; Intellectuals.

Artigo recebido em 03/2008. Aprovado em 07/2008. 
